\title{
Two new free-living nematode species (Trefusiina: Trefusiidae) from the Chatham Rise crest, Southwest Pacific Ocean
}

\author{
Daniel LEDUC \\ National Institute of Water and Atmospheric Research, Private Bag 14-901, Kilbirnie, Wellington, \\ New Zealand, Email: Daniel.Leduc@niwa.co.nz \\ urn:1sid:zoobank.org:author:9393949F-3426-4EE2-8BDE-DEFFACE3D9BC
}

\begin{abstract}
Two new species of the family Trefusiidae, viz., Trefusia piperata sp. nov. and Trefusialaimus idrisi sp. nov., are described from the crest of the Chatham Rise, Southwest Pacific Ocean (350 m water depth). The present study provides the first species records for this family in the region. Trefusia and Trefusialaimus comprise twenty and three valid species, respectively. A key to males of Trefusia is provided.
\end{abstract}

Keywords. Trefusia piperata sp. nov., Trefusialaimus idrisi sp. nov., New Zealand, continental slope, dichotomous key, sandy sediment.

Leduc D. 2013. Two new free-living nematode species (Trefusiina: Trefusiidae) from the Chatham Rise crest, Southwest Pacific Ocean. European Journal of Taxonomy 55: 1-13. http://dx.doi.org/10.5852/ejt.2013.55

\section{Introduction}

Recent studies show high levels of nematode alpha (local) and beta (turnover) diversity on the continental slope of New Zealand (Leduc et al. $2012 \mathrm{a}, \mathrm{b}$ ). The systematics of several free-living marine nematode taxa, however, remains unstudied in the region. One such taxon is the family Trefusiidae, for which no species records exist to date (Leduc \& Gwyther 2008). Surveys of nematode communities on Chatham Rise and Challenger Plateau suggest the presence of at least twelve Trefusiidae morphospecies (Leduc et al. 2012a; D. Leduc unpublished data). The low density of most species in deep-sea habitats, however, often impedes the description of new species (e.g., Miljutin et al. 2010).

Most records of Trefusia De Man, 1893 and Trefusialaimus Riemann, 1974 are from relatively coarse (sandy) sediments (e.g., Riemann 1974; Keppner 1992; Van Gaever et al. 2004; Riera et al. 2010). Trefusia has been recorded in a variety of deep-sea habitats such as manganese nodule deposits (Bussau 1993; Miljutin et al. 2010), canyons (Vitiello 1970), and mounds (Van Gaever et al. 2004). Trefusialaimus is a rare genus and, until now, had only been recorded from the Arctic Ocean (Filipjev 1946) and Northeast Atlantic (Riemann 1974). Here, two new species, Trefusia piperata sp. nov. and Trefusialaimus idrisi sp. nov., are described from sandy sediments on the continental slope of New Zealand. 


\section{Methods}

Sediment samples were obtained from Chatham Rise, a submarine ridge that extends eastwards from the South Island of New Zealand, from depths of $c a$. 250 to $3000 \mathrm{~m}$. Samples were collected in February 2011 during National Institute of Water and Atmospheric Research (NIWA) cruise TAN1103, from a site near central Chatham Rise crest at a depth of $350 \mathrm{~m}\left(43.331^{\circ} \mathrm{S}, 178.288^{\circ} \mathrm{E}\right)$ (see Leduc \& Pilditch 2013 for details of sampling site).

A total of 15 sediment samples was collected, using an Ocean Instruments MC-800A multicorer (MUC; core internal diameter $=9.5 \mathrm{~cm}$ ). Samples were obtained from ten MUC deployments from the sampling site. Each sample consisted of one subcore of internal diameter $26 \mathrm{~mm}$ taken to a depth of $5 \mathrm{~cm}$. Cores were split into $0-1,1-3$, and 3-5 cm sediment depth layers, fixed in $10 \%$ formalin and stained with Rose Bengal. Samples were subsequently rinsed on a $1 \mathrm{~mm}$ sieve to remove large particles and on a $45 \mu \mathrm{m}$ sieve to retain nematodes. Nematodes were extracted from the remaining sediments by Ludox flotation and transferred to pure glycerol (Somerfield \& Warwick 1996). Species descriptions were made from glycerol mounts using differential interference contrast microscopy (10-1000× magnification) and drawings were made with the aid of a camera lucida. Measurements (in $\mu \mathrm{m}$ ) were made using image analysis software (cellSens Standard 1.6), and all curved structures are measured along the arc. Type specimens are held in the NIWA Invertebrate Collection (NIC), Wellington.

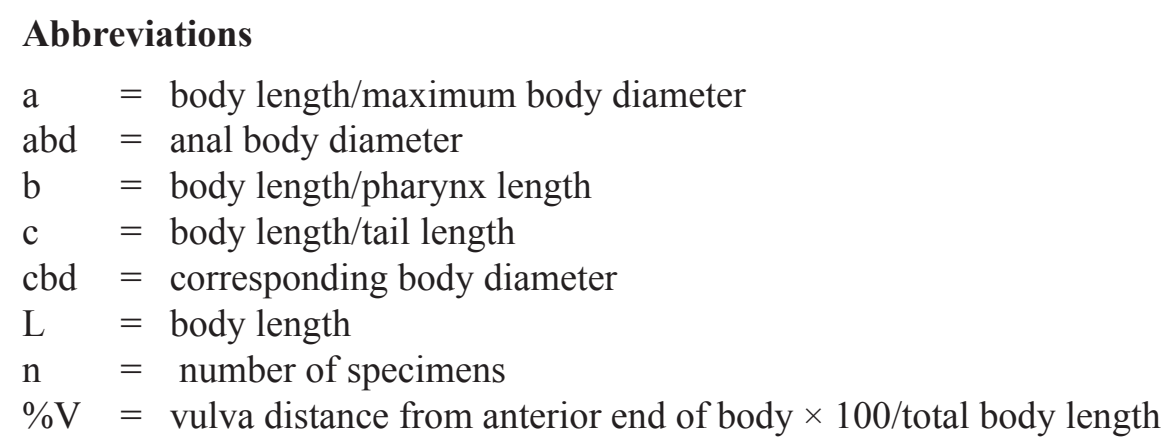

\section{Results}

Family Trefusiidae Lorenzen, 1981

\section{Diagnosis}

Cuticle smooth or with faint striations. Metanemes absent. Amphid either spiral or non-spiral. Outer labial sensillae and cephalic setae usually in two separate circles (except in Trefusialaimus); jointed cephalic setae. Buccal cavity funnel- or barrel-shaped, teeth absent. Males usually with two testes (except Trefusialaimus) and females usually with two ovaries.

Genus Trefusia de Man 1893

\section{Type species}

Trefusia longicauda De Man, 1893

\section{Diagnosis}

Amphideal fovea cryptospiral, oval, or horse-shoe shaped. Funnel-shaped buccal cavity. Males with ventral (and sometimes subventral) longitudinal rows of cervical sensillae. Small papillose pre-cloacal supplements present, situated either in a single ventral row or two sub-ventral rows; post-cloacal papillae 
absent. Spicules usually with handle-shaped proximal ends. Females with two ovaries. Tail conical, conico-cylindrical, or filiform.

\section{Remarks}

The last treatment of the genus Trefusia was by Keppner (1992), who provided an updated key to the males of the 17 species of the genus based on Riemann (1966). T. varians Gerlach, 1955 was not included in the key because the original description was based on female specimens only. Since then, Trefusia monodelphis Bussau, 1990 was synonymised with Trichistoma gracile Andrássy, 1985 by Andrássy (2007), and two new species were described by Bussau (1993). There are currently 20 valid Trefusia species (including T. piperata sp. nov.).

Trefusia piperata sp. nov.

Figs 1-2, Table 1

urn:1sid:zoobank.org:act:43C390C6-9807-4050-857F-02E4538D9920

\section{Diagnosis and relationships}

Trefusia piperata sp. nov. is characterised by six double-jointed outer labial setae with conspicuous clusters of dark granules at their base, four cephalic setae at level of amphid, one seta posterior to each amphid, and long filiform tail. Male is characterised by six cervical papillae, eight papillose pre-cloacal supplements, slightly bent spicules, and gubernaculum with funnel-shaped distal portion and pointed projections.

Trefusia piperata sp. nov. most closely resembles T. helgolandica Riemann, 1966, described from subtidal sediments in the German Bight. The two species are similar in the shape and position of the outer labial setae and cephalic setae, as well as in the structure of the spicules and gubernaculum. The new species, however, differs from $T$. helgolandica in head diameter (14-15 vs. 22-25), maximum body width (21-22 vs. $\geq 33$ ), spicule length (24 vs. 38), number of setae posterior to the amphids (one $v s$. two or three), the number and shape of cervical papillae (six papillae with wide base $v s$. thirteen papillae without wide base), and number of pre-cloacal supplements (eight $v s$. fourteen). Trefusia piperata $\mathrm{sp}$. nov. also differs from T. helgolandica in the presence of conspicuous clusters of dark granules at the base of the outer labial setae.

\section{Etymology}

The species name is derived from the latin word piperatus (= peppered), and refers to the conspicuous clusters of dark granules at the base of the cephalic setae.

\section{Material examined}

\section{Holotype}

O, collected on 20 Feb. 2011 (NIWA cruise TAN1103, station 69), central Chatham Rise $\left(43.331^{\circ} \mathrm{S}\right.$, $178.288^{\circ} \mathrm{E}$ ), water depth $350 \mathrm{~m}$, sediment depth $1-5 \mathrm{~cm}$, mean grain size $55-59 \mu \mathrm{m}$, \%sand $55-57 \%$, particle sorting (geometric) 4.1-4.3 (NIWA 88347).

\section{Paratype}

1 , same data as holotype (NIWA 88348).

\section{Description}

\section{Male}

Body cylindrical, slender, tapering slightly towards anterior extremity (Fig. 2C). Cuticle thin, $<1 \mu \mathrm{m}$ thick, with very fine striations, difficult to observe. Head blunt, slightly rounded, with three lips; six 


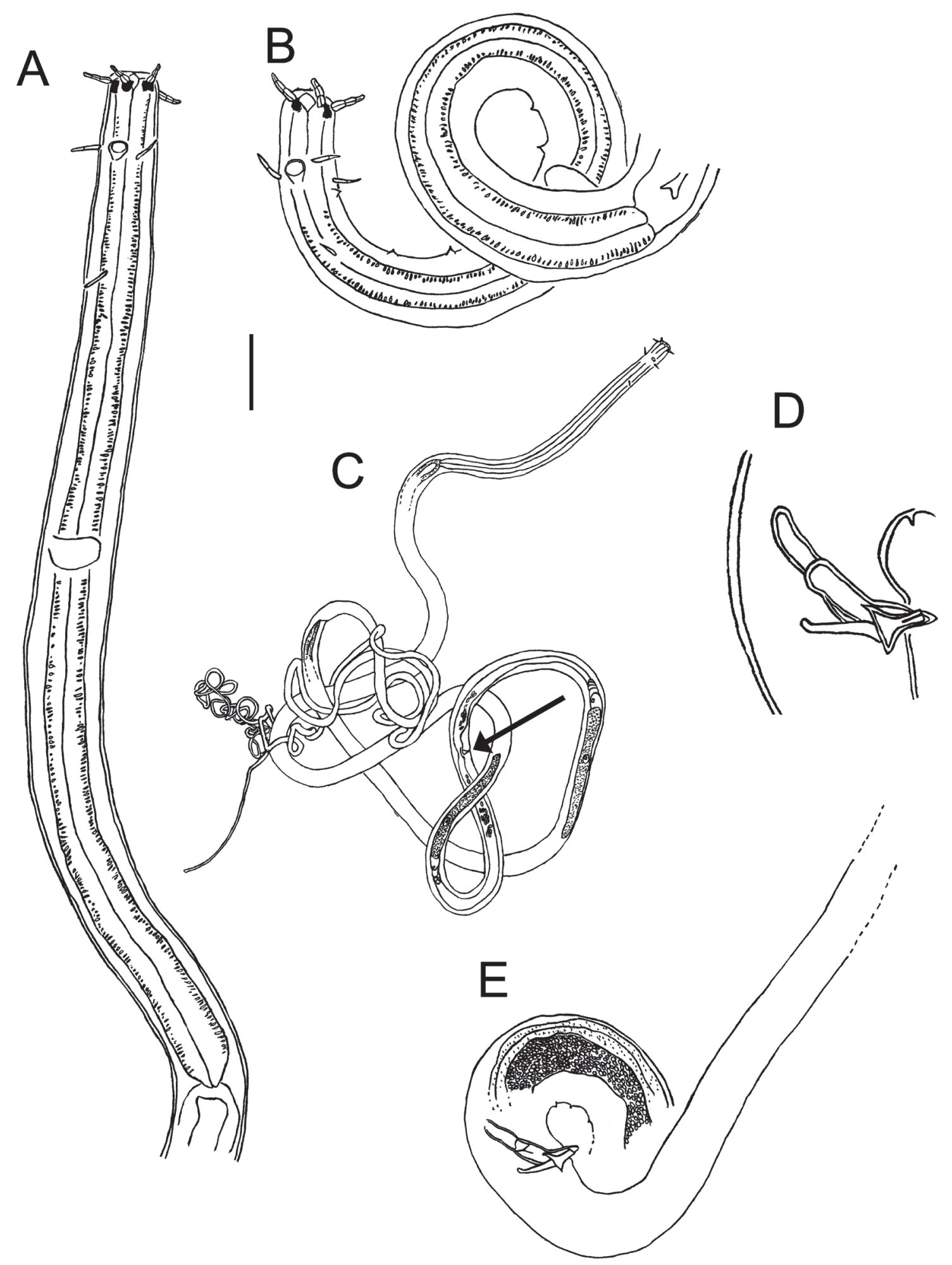

Fig. 1. Trefusia piperata sp. nov. A. Anterior body region of female. B. Anterior body region of male. C. Entire female. D. Right spicule and gubernaculum. E. Posterior body region of male. Arrow shows position of vulva. Scale bar: A-B, $\mathrm{E}=20 \mu \mathrm{m} ; \mathrm{C}=75 \mu \mathrm{m} ; \mathrm{D}=8 \mu \mathrm{m}$. 
small conical inner labial sensillae, $\sim 1 \mu \mathrm{m}$ long, six double-jointed outer labial setae with blunt ends, $c a$. $0.7 \mathrm{cbd}$ (Fig. 1B). Conspicuous clusters of dark brown granules situated at base of each outer labial seta (Fig. 2A). Four cephalic setae at level of amphid, jointed, 5-7 $\mu \mathrm{m}$ long (Fig. 1B). Amphid pocket-shaped with oval aperture, $c a .4 \mu \mathrm{m}$ wide by $2 \mu \mathrm{m}$ high. One seta situated $c a .25 \mu \mathrm{m}$ posterior to each amphid, 5 $\mu \mathrm{m}$ long. No other somatic setae observed. Six small cervical papillae with wide base situated ventrally in longitudinal row; row extends from posterior of amphid to about $60 \%$ of pharynx length from anterior (Fig. 1B). Buccal cavity funnel-shaped, without teeth. Pharynx cylindrical, slightly swollen at anterior
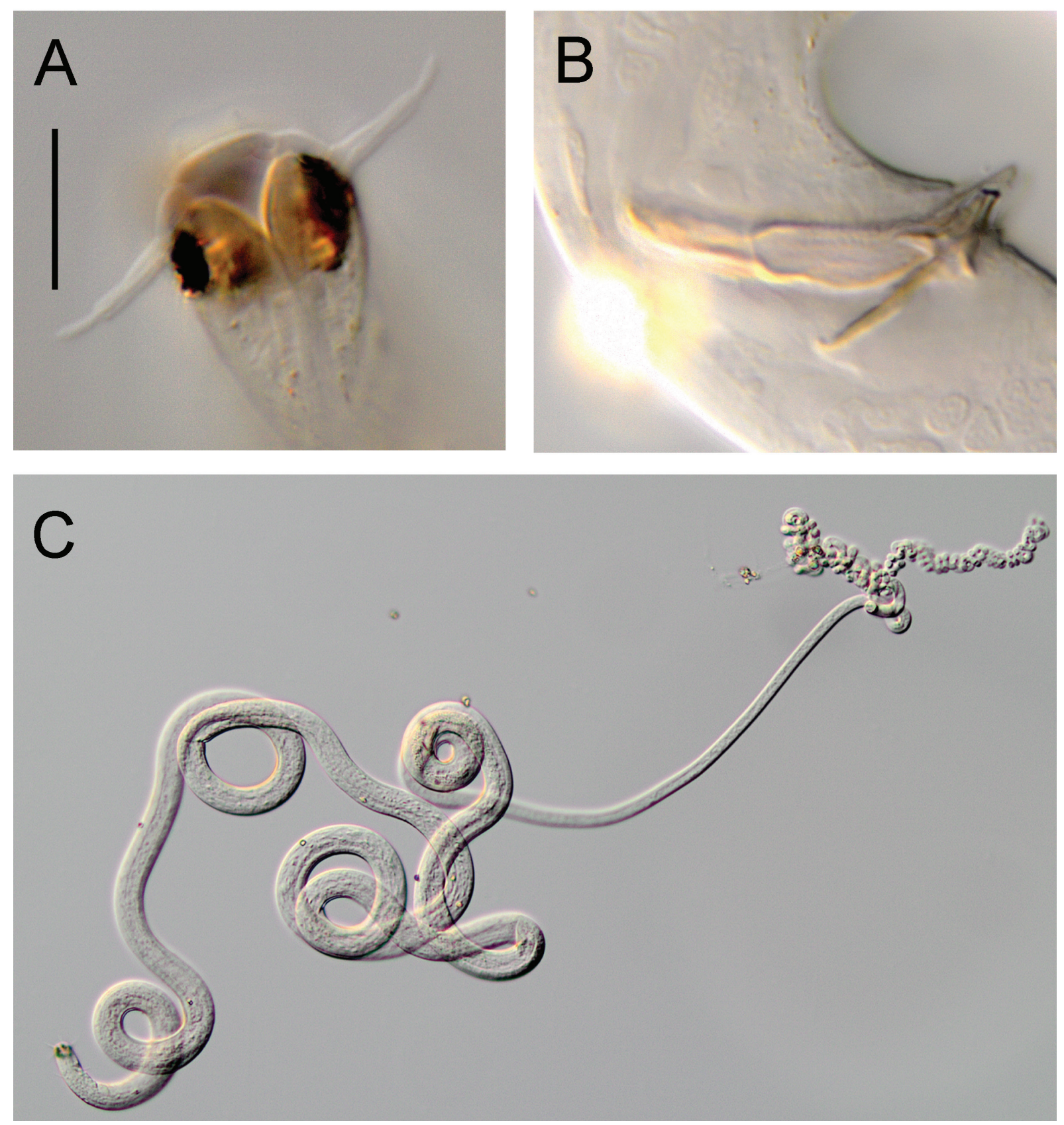

Fig. 2. Trefusia piperata sp. nov. Light micrographs. A. Head region of male, showing buccal cavity, cephalic setae, and clusters of dark granules at base of outer labial setae. B. Spicule and gubernaculum. C. Entire male. Scale bar: A-B $=10 \mu \mathrm{m} ; \mathrm{C}=100 \mu \mathrm{m}$. 
Table 1. Morphometrics ( $\mu \mathrm{m})$ of Trefusia piperata $\mathrm{n}$. sp. and Trefusialaimus idrisi $\mathrm{n}$. sp. (a: body length/ maximum body diameter, abd: anal body diameter, b: body length/pharynx length, c: body length/tail length, cbd: corresponding body diameter, $\mathrm{V}$ : vulva distance from anterior end of body, \% V: V/total body length).

\begin{tabular}{|c|c|c|c|c|}
\hline \multirow[t]{2}{*}{ Species } & \multicolumn{2}{|c|}{ Trefusia piperata sp. nov. } & \multicolumn{2}{|c|}{ Trefusialaimus idrisi sp. nov. } \\
\hline & Holotype $\sigma^{-1}$ & Paratype $q$ & Holotype $\sigma^{\lambda}$ & Paratype juv. \\
\hline $\mathrm{n}$ & & 1 & & 1 \\
\hline $\mathrm{L}$ & 3663 & 4492 & 4539 & 2826 \\
\hline $\mathrm{a}$ & 167 & 214 & 130 & 97 \\
\hline $\mathrm{b}$ & 14 & 16 & 13 & 9 \\
\hline $\mathrm{c}$ & 2 & 2 & 7 & 5 \\
\hline Head diameter* & 14 & 15 & 20 & 17 \\
\hline Mouth diameter & 4 & 3 & 1 & 2 \\
\hline Length of sub-cephalic setae & $5-7$ & $6-7$ & 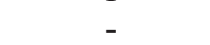 & - \\
\hline Length of cephalic setae & 9 & $7-8$ & $8-10$ & 6 \\
\hline Amphid height & 5 & 4 & 2 & 2 \\
\hline Amphid width & 4 & 3 & 6 & 5 \\
\hline Amphid width/cbd (\%) & 29 & 20 & 30 & 29 \\
\hline Amphid from anterior end & 17 & 19 & 38 & 33 \\
\hline Nerve ring from anterior end & 119 & 117 & 177 & 152 \\
\hline Nerve ring cbd & 22 & 20 & 31 & 27 \\
\hline Pharynx length & 260 & 281 & 357 & 314 \\
\hline Pharyngeal bulb diameter & 13 & 19 & 20 & 17 \\
\hline Pharyngeal bulb cbd & 21 & 14 & 34 & 28 \\
\hline Max. body diameter & 22 & 21 & 35 & 29 \\
\hline Spicule length & 24 & - & 39 & - \\
\hline Gubernaculum length & 9 & - & 14 & - \\
\hline Anal body diameter & 21 & 15 & 17 & 17 \\
\hline Tail length & 1806 & 2330 & 650 & 590 \\
\hline Tail length/abd & 86 & 155 & 38 & 35 \\
\hline V & - & 1383 & - & - \\
\hline$\% \mathrm{~V}$ & - & 31 & - & - \\
\hline Vulval body diameter & - & 21 & - & - \\
\hline
\end{tabular}

*at level of cephalic setae

and posterior extremities, completely surrounds buccal cavity. Nerve ring situated at ca. $45 \%$ of pharynx length from anterior extremity. Secretory-excretory system not observed. Cardia very small.

Reproductive system diorchic with outstretched testes. Position of testes relative to intestine difficult to ascertain. Sperm cells drop-shaped with rod-shaped nucleus; vas deferens $c a .445 \mu \mathrm{m}$ long. Paired, equal spicules, slightly bent near distal one third, without obvious central cuticularised projection (i.e., lamella or median rib). Gubernaculum with narrow proximal region and funnel-shaped distal region with large anterior pointed projection and smaller posterior pointed projection (Figs 1D, 2B). Eight small papillose pre-cloacal supplements situated ventrally, 6-15 $\mu \mathrm{m}$ apart except for anterior-most supplement which is situated $40 \mu \mathrm{m}$ from next supplement. Tail very long, $c a$. half of total body length, filiform, without setae, tightly coiled.

\section{Female}

Similar to male, but with slightly shorter cephalic setae and slightly smaller amphid (Fig. 1A). Female reproductive system didelphic, amphidelphic with reflexed ovaries. Position of ovaries relative to the intestine difficult to ascertain. Vulva situated at one third of body length (Fig. 1C). 


\section{Discussion}

Trefusia piperata sp. nov. was rare at the study site, with only four specimens (the two type specimens and two juveniles in poor condition, each from a different subcore) recorded out of the 4412 individuals that were identified by Leduc \& Pilditch (2013). Two individuals were found in the $1-3 \mathrm{~cm}$ sediment depth layers, and two were found in the 3-5 cm sediment depth layer (D. Leduc, unpublished data).

Key to the males of Trefusia (modified from Keppner 1992):

1 Large complex sensillae present on ventral surface in cervical region

- Large complex sensillae absent on ventral surface in cervical region; small papilliform sensillae

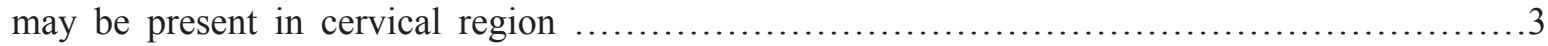

2 Complex cervical sensillae pyriform; spicules narrow, arcuate; tail 7.4 abd long T. honessi Keppner, 1986

- Complex cervical sensillae circular; spicules broad with bladder-like structure on ventral side; tail 1517 abd long T. americana Keppner, 1992

3 Circle of four cephalic sensillae distinctly anterior to amphid ............................

- Circle of four cephalic sensillae in region of, or posterior to amphid ........................... 8

4 Spicules 6.8-7.4 abd long; gubernaculum present T. filicauda Allgén, 1933

- Spicules less than $2.5 \mathrm{cbd}$; gubernaculum present or absent . .5

5 Amphid situated $\geq 3$ cbd from anterior extremity ........................ attenuata Bussau, 1993

- Amphid situated $<3$ cbd from anterior extremity

6 Amphid aperture circular T. dominatrix Bussau, 1993

- Amphid aperture oval

7 Amphid aperture transversely oval; tail 4.0 abd long T. cornea Gerlach, 1958

- Amphid aperture longitudinally oval; tail 20 abd long T. axonolaimoides Allgén, 1953

8 Tail short, conical, 1.0 abd long

T. conica Gerlach, 1957

- Tail long, conical to filiform, greater than 5.0 abd long

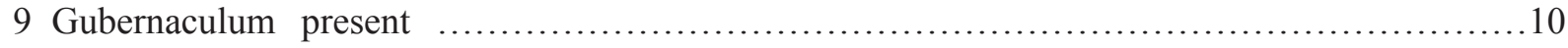

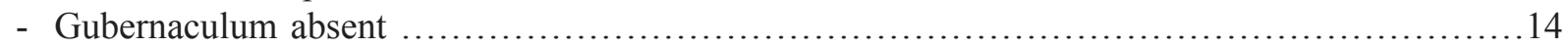

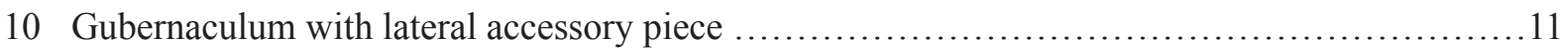

- Gubernaculum without lateral accessory piece .....................T. spatulata Keppner, 1992

11 Circle of four sub-cephalic sensillae posterior to amphid; spicules with strong arc

T. zostericola Allgén, 1933

- Circle of four sub-cephalic sensillae at level of amphid; spicules without strong arc ...........12

12 Lateral piece of gubernaculum distinct; spicules without distinct outer median rib (lamella) ......13

- Lateral piece of gubernaculum not distinct; spicules with distinct, outer, median rib; cervical region with single setiform postamphidial sensilla .T. longicauda De Man, 1893

13 Cervical region with two or three setae posterior to each amphid; male with longitudinal row of 13 papillae in cervical region; no clusters of dark granules at base of cephalic setae ..T. helgolandica Riemann, 1966 
- Cervical region with one seta posterior to each amphid; male with longitudinal row of six papillae on wide base in cervical region; clusters of dark granules at base of cephalic setae

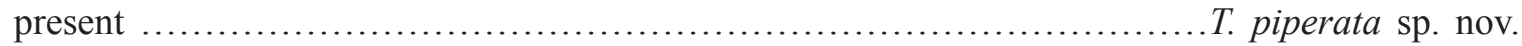

14 Cervical and pre-cloacal papilliform supplements present on ventral surface; c greater than 5.1

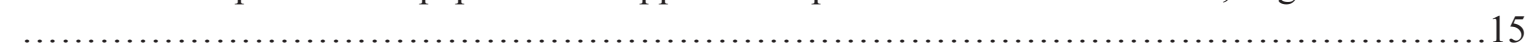

- Cervical and pre-cloacal papilliform sensillae absent from ventral surface; $\mathrm{c}=2.8$ T. pseudolittoralis Vitiello, 1970

15 Spicules slender, gently curved, capitulum not broad and elongate ........................16

- Spicules broad, acutely curved, capitulum broad and elongate ...........................17

16 Pre-cloacal papilliform sensillae $12-18$ in number; $\mathrm{a}=112-129$

T. multipapillatum Bouwman, 1981

- $\quad$ Pre-cloacal papilliform sensillae 5-7 in number; $\mathrm{a}=70-87$ T. littoralis Allgén, 1932

17 Capitulum of spicules with elongate ventral projection ...T. curvispiculosa Vincx \& Vanreusel, 1989

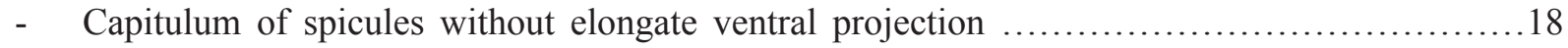

18 Circle of four sub-cephalic setae posterior to amphid; excretory pore heavily cuticularised; $a=88-117$ ..T. longicorpa Keppner, 1986

- Circle of four sub-cephalic setae at level of amphid; excretory pore not observed; $a=53-57 \ldots \ldots$. .T. schiemeri Ott, 1977

Genus Trefusialaimus Riemann, 1974

\section{Type species}

Trefusialaimus monorchis Riemann, 1974

\section{Diagnosis}

Sub-cephalic and somatic setae absent. Ten cephalic setae in one circle; amphid pocket-shaped. Male with one testis and peri-cloacal papillae. Elongated sperm cells with central rod and light-refractive nucleus at one extremity. Tail conico-cylindrical or filiform.

Trefusialaimus idrisi sp. nov.

Figs 3-4; Table 1

urn:1sid:zoobank.org:act:56BD1B40-542A-4FE2-BB84-F8FC7C5C2667

\section{Diagnosis and relationships}

Trefusialaimus idrisi sp. nov. is characterised by relatively short body length, presence of numerous golden inclusions in the chords, cephalic setae $0.65-0.80 \mathrm{cbd}$ long, spicules $2.3 \mathrm{abd}$ long, 4 pairs of pericloacal papillae, and long, gradually tapering tail.

Until now, only two Trefusialaimus had been described, viz., T. magnus (Filipjev, 1946) and T. monorchis Riemann, 1974. Trefusialaimus idrisi sp. nov. is similar to T. magnus in the shape of the copulatory apparatus and tail, but can be differentiated from the latter by the shorter body length (4540 vs. 7700 $\mu \mathrm{m})$, lower value of c (7 vs. 21), longer cephalic setae (0.65-0.80 vs. $0.4 \mathrm{cbd})$, longer spicules (2.3 vs. $1.7 \mathrm{abd}$ ), and longer tail ( $38 \mathrm{vs} .11 \mathrm{abd})$. T. idrisi sp. nov. can easily be differentiated from T. monorchis by the markedly longer cephalic setae (0.65-0.80 vs. $0.26 \mathrm{cbd})$, absence of pre- and post-cloacal papillae (present in T. monorchis), and tail shape (gradually tapering $v s$. conico-cylindrical). 


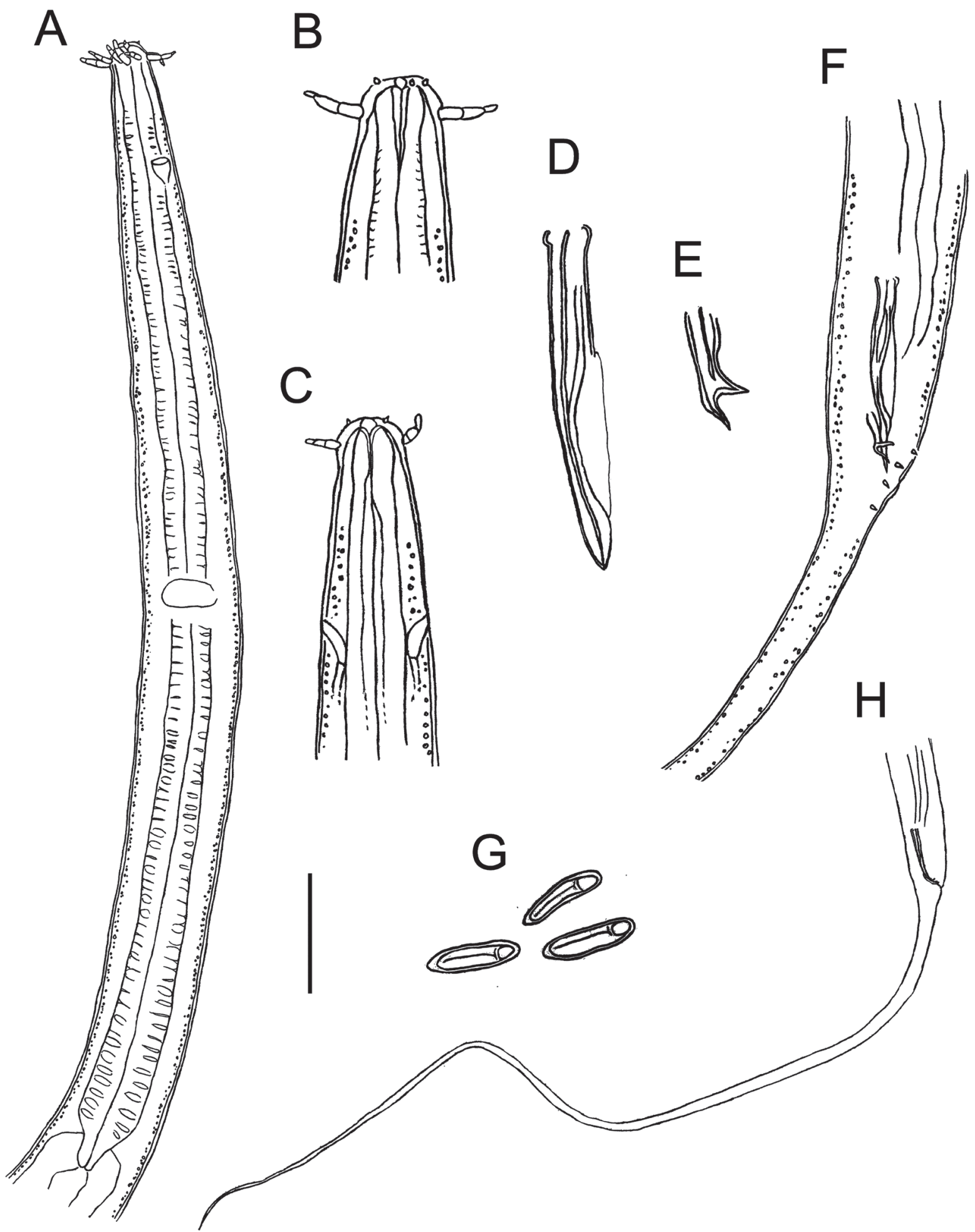

Fig. 3. Trefusialaimus idrisi sp. nov. A. Anterior body region of male. B. Head of male. C. Head of juvenile. D. Right spicule. E. Gubernaculum. F. Male copulatory apparatus. G. Mature sperm. H. Posterior body region of male. Scale bar: A $=40 \mu \mathrm{m}$; B-C, $\mathrm{G}=20 \mu \mathrm{m}$; D-E $=14 \mu \mathrm{m} ; \mathrm{F}=28 \mu \mathrm{m} ; \mathrm{H}=$ $75 \mu \mathrm{m}$. 

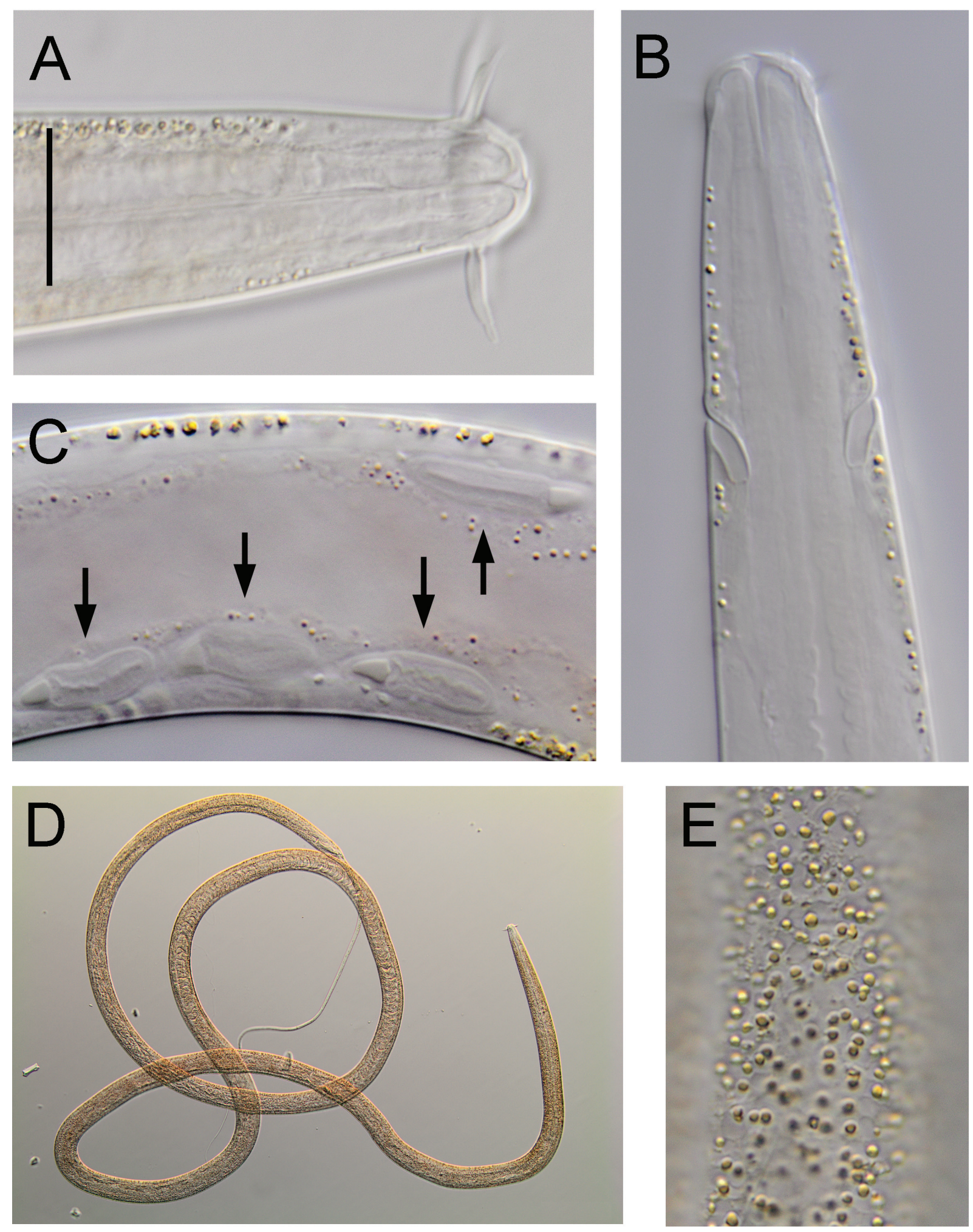

Fig. 4. Trefusialaimus idrisi sp. nov. Light micrographs. A. Anterior body region of male, lateral view. B. Anterior body region of juvenile, dorsal view. C. Mid-body region of juvenile, showing sperm cells in pseudocoelom. D. Entire male. E. Lateral chord of male, showing round golden inclusions. Arrows point to sperm cells. Scale bar: A-C, $\mathrm{E}=15 \mu \mathrm{m} ; \mathrm{D}=260 \mu \mathrm{m}$. 


\section{Etymology}

The species is named after Idris Matai Kljucanin Brun, the author's godson.

\section{Material examined}

\section{Holotype}

\%, collected on 20 Feb. 2011 (NIWA cruise TAN1103, station 69), central Chatham Rise $\left(43.331^{\circ} \mathrm{S}\right.$, $178.288^{\circ} \mathrm{E}$ ), water depth $350 \mathrm{~m}$, sediment depth $1-5 \mathrm{~cm}$, mean grain size $55-59 \mu \mathrm{m}$, \%sand $55-57 \%$, particle sorting (geometric) 4.1-4.3 (NIWA 88349).

\section{Paratype}

1 juvenile, same data as holotype (NIWA 88350).

\section{Description}

\section{Male}

Body cylindrical, slender, tapering slightly towards anterior extremity (Fig. 4D), with slight golden colouration due to the presence of numerous round, $c a .1 \mu \mathrm{m}$ diameter, golden inclusions in the chords (i.e., longitudinal thickenings of the hypodermis protruding internally between the sectors of the longitudinal muscles; Chitwood \& Chitwood 1974) (Fig. 4E). Cuticle smooth, thin, ca. 0.7-0.9 $\mu \mathrm{m}$ thick, except in head region (anterior to cephalic setae) where it is slightly thicker, 1.0-1.6 $\mu \mathrm{m}$. Head rounded, slightly set-off from body due to thickened cuticle, with three lips, each bearing two small, conical inner labial papillae 1.0-1.5 $\mu \mathrm{m}$ long (Fig. 3B). Six outer labial setae and four cephalic setae in one circle, double-jointed; cephalic setae slightly longer than outer labial setae $(0.75-0.80 \mathrm{cbd} v \mathrm{~s}$. $0.65 \mathrm{cbd})$. Sub-cephalic and somatic setae absent. Amphid pocket-shaped with oval aperture, $c a .6$ $\mu \mathrm{m}$ wide by $2 \mu \mathrm{m}$ high (Fig. 3A). Buccal cavity funnel-shaped, without teeth. Pharynx cylindrical, slightly swollen at posterior extremity, completely surrounds buccal cavity. Pharyngeal lumen lightly but distinctly cuticularised at anterior extremity (Figs 3B, 4B). Nerve ring situated at $c a$. 50\% of pharynx length. Secretory-excretory system not observed. Cardia small.

Reproductive system monorchic with single outstretched testis, $c a .1960 \mu \mathrm{m}$ long. Position of testis relative to intestine difficult to ascertain. Elongated sperm cells, ca 3-5 $\mu \mathrm{m}$ wide by $13-16 \mu \mathrm{m}$ long, with central rod and nucleus at one extremity (Fig. 3G); vas deferens $c a .520 \mu \mathrm{m}$ long, without muscular ejaculatory duct. Paired, equal spicules, 2.3 abd long, slightly bent near distal one third, with broad proximal end and narrow pointed distal end; velum present (Fig. 3D). Gubernaculum with two pairs of narrow, pointed lateral crurae (Fig. 3E). Four pairs of small, conical peri-cloacal papillae (Fig. 3F). Precloacal supplements absent. Tail long, $c a$. $14 \%$ of total body length, narrow, gradually tapering, without setae (Fig. 3H).

\section{Juvenile}

Similar to male, but with shorter and narrower body, shorter cephalic setae (Figs 3C, 4B), and smaller amphid. Numerous sperm cells are present throughout the pseudocoelom from $c a$. $90 \mu \mathrm{m}$ posterior to pharynx to $c a .200 \mu \mathrm{m}$ anterior to anus (Fig. 4C). Genital and copulatory (i.e., cloacal or vulval) primordia not observed.

\section{Discussion}

The presence of sperm cells in the pseudocoelom of the juvenile Trefusialaimus idrisi sp. nov. specimen is unusual. Some nematode species, such as Oncholaimus oxyuris, can transfer sperm through traumatic insemination (Coomans et al. 1988), a process whereby the male injects sperm directly into the body of a female (or potentially even a male or juvenile) by piercing the cuticle with the spicules. The presence of sperm cells in the juvenile specimen could be explained if a similar process occured in T. idrisi sp. nov. 
The existence of such a reproductive strategy, however, is highly conjectural because no Trefusialaimus females have ever been observed and (to my knowledge) traumatic insemination has not been described in the suborder Trefusiina.

Trefusialaimus idrisi sp. nov. was rare at the study site, with only four specimens (the two type specimens and two juveniles in poor condition, each from a different subcore) recorded out of the 4412 individuals that were identified by Leduc \& Pilditch (2013). All individuals were found in the surface $(0-1 \mathrm{~cm})$ sediment layer (D. Leduc, unpublished data). A single juvenile specimen (out of 4550 specimens identified from 30 locations on the New Zealand continental margin) was recorded from a site on the northern flank of Chatham Rise at a depth of $1000 \mathrm{~m}\left(178.500^{\circ} \mathrm{E}, 44.333^{\circ} \mathrm{S}\right.$; silt/clay content $\left.95 \%\right)$ (Leduc et al. 2012a; D. Leduc unpublished data).

\section{Acknowledgements}

Funding was provided by FRST through a postdoctoral fellowship to D. Leduc (UOOX0909), the programme "Coasts \& Oceans OBI" (C01X0501), and NIWA by Coasts and Oceans Centre Research Programme 2 (2012/13 SCI). I am thankful to Scott Nodder (NIWA) for facilitating sample collection, Keith Probert (University of Otago) for his support and guidance, Anna Lawless (University of Waikato) for her help with processing of multicorer samples onboard RV Tangaroa, and Anne-Nina Lorz for her help with the translation of Riemann's original species descriptions. I am grateful to two anonymous reviewers for providing constructive criticisms on the manuscript. I also acknowledge the other participants of voyage TAN1103, and the officers and crew of RV Tangaroa.

\section{References}

Andrássy I. 2007. Free living nematodes of Hungary, II (Nematoda errantia). Pedozoologica Hungarica 4: 1-496.

Bussau C. 1993. Taxonomische und ökologische Untersuchungen an Nematoden des Peru-Beckens. $\mathrm{PhD}$ dissertation, Kiel.

Chitwood B.G. \& Chitwood M.B. 1977. Introduction to Nematology. University Park Press, Baltimore.

Coomans A., Verschuren D. \& Vanderhaeghen R. 1988. The demanian system, traumatic insemination and reproductive strategy in Oncholaimus oxyuris Ditlevsen (Nematoda, Oncholaimina). Zoologica Scripta 17: 15-23. http://dx.doi.org/10.1111/j.1463-6409.1988.tb00083.x

Keppner E.J. 1992. Some free-living nematodes from Northwest Florida, U.S.A. with description of three new species (Nematoda: Chromadorida, Trefussida). Transactions of the American Microscopical Society 111: 199-210. http://www.jstor.org/stable/3226609

Leduc D. \& Gwyther J. 2008. Description of new species of Setosabatieria and Desmolaimus (Nematoda: Monhysterida) and a checklist of New Zealand free-living marine nematode species. New Zealand Journal of Marine and Freshwater Research 42:339-362. http://dx.doi.org/10.1080/00288330809509962

Leduc D. \& Pilditch C. 2013. Effect of a physical disturbance event on deep-sea nematode community structure and ecosystem function. Journal of Experimental Marine Biology and Ecology 440: 35-41. http://dx.doi.org/10.1016/j.jembe.2012.11.015

Leduc D., Rowden A.A., Bowden D.A., Nodder S.D., Probert P.K., Pilditch C.A., Duineveld G.C.A. \& Witbaard R. 2012a. Nematode beta diversity on the continental slope of New Zealand: spatial patterns and environmental drivers. Marine Ecology Progress Series 454: 37-52. http://dx.doi.org/10.3354/ meps09690

Leduc D., Rowden A.A., Bowden D.A., Probert P.K., Pilditch C.A. \& Nodder S.D. 2012b. Unimodal relationship between biomass and species richness of deep-sea nematodes: implications for the link 
between productivity and diversity. Marine Ecology Progress Series 454: 53-64. http://dx.doi. org/10.3354/meps09609

Miljutin D.M., Gad G., Miljutina M.M., Mokievsky V.O., Fonseca-Genevois V., Esteves A.M. 2010. The state of knowledge on deep-sea nematode taxonomy: how many valid species are known down there? Marine Biodiversity 40: 143-159. http://dx.doi.org/10.1007/s12526-010-0041-4

Riemann F. 1966. Die Gattung Trefusia De Man, 1893 (Enoplida: Oxystominidae). Beiträge zum natürlichen System freilebender Nematoden. Veröffentlichungen zur Meeresforschung Bremerhaven 10: $1-29$.

Riemann F. 1974. Trefusialaimus nov. gen. (Nematoda) aus der Iberischen Tiefsee mit Diskussion des männlichen Genitalapparates von Enoplida Tripyloidea. Meteor Forschungsergebnisse 18: 39-43.

Riera R., Núñez J. \& del Carmen Brito M. 2010. Trefusiids (Nematoda, Trefusiida) from the Canary Islands. Revista de la Academia Canaria de Ciencias 22(3): 103-109.

Somerfield P.J. \& Warwick R.M. 1996. Meiofauna in Marine Pollution Monitoring Programmes: a Laboratory Manual. Ministry of Agriculture, Fisheries and Food, Lowestoft.

Van Gaever S., Vanreusel A., Hughes J.A., Bett B. \& Kirikoualis K. 2004. The macro- and microscale patchiness of meiobenthos associated with the Darwin Mounds (north-east Atlantic). Journal of the Marine Biological Association of the United Kingdom 84: 547-556. http://dx.doi.org/10.1017/ $\underline{\mathrm{S} 0025315404009555 \mathrm{~h}}$

Vitiello P. 1970. Nématodes libres marins des vases profondes du Golfe du Lion. I. Enoplida. Téthys 2: 139-210.

Manuscript received: 3 April 2013

Manuscript accepted: 26 July 2013

Published on: 5 September 2013

Topic editor: Rudy Jocqué

Desk editor: Kristiaan Hoedemakers

Printed versions of all papers are also deposited in the libraries of the institutes that are members of the EJT consortium: Muséum National d'Histoire Naturelle, Paris, France; National Botanic Garden of Belgium, Meise, Belgium; Royal Museum for Central Africa, Tervuren, Belgium; Natural History Museum, London, United Kingdom; Royal Belgian Institute of Natural Sciences, Brussels, Belgium; Natural History Museum of Denmark, Copenhagen, Denmark. 